\title{
The Silviculture Conference Self-government, land claims and silviculture: An aboriginal forest strategy
}

\author{
by Debra Wright
}

Until recently it was possible to envision Canada as an endless expanse of trees stretching from sea to sea. Today, however, our forests are in serious jeopardy. It has even been said that in British Columbia, trees are being toppled "perhaps faster than anywhere else in the world". It is in a milieu of diminishing resources and increasingly entrenched industry interestes that Aboriginal forestry is unfolding.

There are as many views on Aboriginal forestry as there are trees in the woods. It means many things to many people. More than anything else, what sets Aboriginal forestry apart from other forms of forestry is a deeply rooted system of land ethics and values which have evolved over tens of thousands of years.

Every person on this Earth has a land ethic, or relationship with the land, whether it is based on carelessness, apathy, love, domination, respect or spirituality. The relationship of Aboriginal peoples with the land is the fundamental essence of our understanding of who we are as individuals, families and communities. We see ourselves as a small and very dependent part of a larger web. With this perspective, one quickly develops a direct understanding of action and consequences with respect to land use. Practices emanating from this belief system embody a sense of respect for the elders, and embrace freedom of choice and strong relationships within the family and community.

Ideally, the practice of Aboriginal forestry would lead to sustainable community development and a balanced use of resources. In reality, the walk towards forestry development for us is not that simple. Given the often overwhelming economic and social challenges facing Aboriginal communities in Canada, we are struggling with the question of how to preserve our traditions with a shrinking land base largely controlled by profit-oriented forest companies. The responses are as numerous and complex as the forces at play in our lives. Some say go with the old, some say go with the new, and others suggest that we try to do both.

For many Aboriginal peoples, engaging in forestry means trying to find a middle ground between the tug and pull of their community's profound needs for cultural preservation and economic development. George Erasmus, former National Chief of the Assembly of First Nations, expressed this sentiment well:

Conservation and development, policy-making and planning often seem to assume that we, the Aboriginal peoples, have only two options for the future: to return to our ancient way of life or to abandon subsistence altogether and become assimilated into the dominant society. Neither option is reasonable. We should have a third option: to modify our subsistence way of life, combining the old and new in ways that maintain and enhance our identity while allowing our society and economy to evolve.

National Aboriginal Forestry Association, 875 Bank St., Ottawa, Ontario, Canada K1G 3W4.
The community of Tachie in north central British Columbia is combining old and new ways through Tanizul Timber Ltd., a budding forestry company owned and operated by members of the Tl'azt'en Nation. In 1981, the company outbid other competitors in securing a 25 -year license to harvest and manage 49,700 hectares of nearby forest land. Tanizul Timber is the largest Aboriginal forestry operation in the province, and provides muchneeded jobs for local Aboriginal people, in addition to boosting the community economy.

Tanizul Timber is a showpiece of success in the field of Aboriginal forestry in Canada, yet even the president, Ed John, wonders about the cultural costs associated with the fast pace of change brough on by the business. At a conference on Aboriginal forestry in 1990, he raised these questions, "How will we as Aboriginal peoples manage these changes? As our lifestyle changes, what values of our people will survive?"

Aboriginal values play a key role in the development of an Aboriginal forestry. Aboriginal foresters perceive their participation in the forest industry as being much broader than the mere removal of trees from the forest. Aboriginal forestry involves the care and management of the entire ecosystem for an area, ensuring that their forestry practices do not threaten the continuation of a diverse and healthy wildlife habitat.

For instance, Aboriginal values are evident in Aboriginal silviculture practices. Our interest is in regeneration of an entire habitat, therefore we take great care with respect to the use of pesticides and herbicides. As well, replanting is not necessarily limited to one or two species but may include plants that are of cultural importance to us, such as black ash which we use in our baskets or certain berries or medicinal plants.

Aboriginal foresters recognize that healthy ecosystems form a basis for healthy economies. Healthy forests can support a broad range of economic activities for Aboriginal communities, such as hunting, fishing, trapping, tourism, logging, and the management of wildlife resources and of the forests themselves.

For many Aboriginal peoples in Canada, the forests are our home, our hunting grounds, our ceremonial lands. Forests are of vital importance to us and they are falling with unprecedented speed, at the hands of industry and due to maligned government policy. Forests have sustained and engaged us for centuries. Yet, forestry in Canada, as it is practised today, has developed largely without our participation or consultation with regard to use of, or impacts on, traditional territories and other areas significant to culture and livelihood. As the original inhabitants of this vast land, we are now more aggressively exercising our rights to manage and benefit from the forest and its resources.

Increased participation of Aboriginal peoples in forestry activities is often seen as a means of job creation; however, it is also a vehicle for community stability and self-respect, environmental and cultural enhancement, and an avenue out of economic depression. In the broadest sense, therefore, of economic, social and environmental development, increased Aboriginal participation in the forest sector may be especially important to Aboriginal 
people. In our view, the forest sector offers the most natural avenue for Aboriginal communities to escape dependence on well-meaning but demeaning welfare programs and to stand tall as selfsufficient communities making a contribution to the Canadian economy. Working in a familiar forest environment would mean one less hurdle for Aboriginal people to overcome. It would be much easier to maintain traditional values and ties to the land while working in the forest sector, than it would be if we have to migrate to urban centres in search of jobs. To many of the Aboriginal communities in Canada, forestry is the only game in town; there are very few other options for employment.

At the present time, however, there is a minimal level of participation by Aboriginal people in the forest sector. The forest industry in Canada is one of the largest in the world, producing forest products valued at approximately $\$ 48$ billion annually. The forest industry and related businesses employ up to 900,000 people in Canada, yet despite the fact that more than 85 per cent of Aboriginal communities are located in productive forest areas, the economic and employment benefits accrued by Aboriginal people from the industry are dismally low. According to the 1986 census, only 4,255 Aboriginal people were employed in forestry and logging occupations at that time, $7 \%$ of the total workforce for that sector.

Timber harvesting, processing, reforestation, wildlife management and other forest resource management activities offer some of the most logical business and employment opportunities for Aboriginal people, however there are barriers which must be overcome before such opportunities can be fully realized.

The first of these barriers is the antiquated federal legislation and policy regime which First Nations in Canada are bound by; a system which Aboriginal peoples did not set up and do not manage.

Currently, we operate within the confines of the Indian Act, Canada's federal legislation which has dictated how we conduct our affairs for over a century. The Act is woefully inadequate when it comes to forestry, since it covers only the cutting and sale of timber on reserve lands. No provisions are made for forest management, nor are the federal fiduciary responsibilities clearly delineated as they relate to First Nations' governments.

The Indian Act's accompanying Indian Timber Regulations, enacted in 1954, were found by Canada's Auditor General in his annual report to the House of Commons in November 1992, to be "silent on virtually all of the modern forestry practices that would ensure harvesting of Indian Timber on a sustainedyield basis." The Auditor General's indictment of federal mismanagement of Aboriginal forests is further evidence of the need for radical reform. He found that the Indian Affairs department has been negligent in its handling of Aboriginal forestry affairs, namely that it has not acted with "professional and due care".

On many reserves, most of the prime timber has already been logged, with little attention paid to reforestation and management. The impact of these practices on our traditional way of life has been devastating. There is a critical need for new legislation and policies on forestry to hand over greater control to First Nations in forestry matters. Without this, forests both on reserves and in our traditional territories will continue to suffer from serious environmental, cultural and economic degradation.

The small size of Indian reserves, however, and the absence of any land base for some Aboriginal communities are major barriers to effective participation in the forest sector.

Another barrier is the restrictions placed on Aboriginal forestry practices within current land tenure arrangements. From the Aboriginal perspective, existing tenure systems place too much emphasis on timber production. When a First Nation enterprise enters into a tenure arrangement, or obtains a license, it is required to conform to forest values which do not accommodate traditional use. Furthermore, the provincial royalty systems perpetuate the orientation to fibre production thereby discouraging Aboriginal forestry development. As well, provincial land tenure systems do not recognize Aboriginal and treaty rights, and the economic benefits to a community from subsistence activities. Nor do they recognize the economic potential which could be derived from such activities as cultural tourism, and the production of Native-made wood and non-wood products. In summary, restrictions within the current land tenure system do not accommodate integrated forest management regimes, therefore many Aboriginal forestry operations end up having to put the cultural needs of their community on the back burner.

A third and very important barrier is the lack of control that we have over our reserve and traditional lands. As Aboriginal people, we are more than just another category of public interest group. We are the original stakeholders in this country. We have Aboriginal and treaty rights which are unique. Many of us remain totally dependant on the diverse productivity of the forest environment. For the most part, however, we have minimal, or no involvement at all in the resource management decision-making for our traditional areas.

A fourth barrier is the need for increased skill development, specifically a training environment where traditional skills and knowledge can be blended with modern skills and knowledge to develop new forestry practices which incorporate Aboriginal values. Someone asked me the other day about the wisdom of training Aboriginal people for employment in an industry which is facing restructuring and massive layoffs. My answer alluded to the "chicken and egg" question - "which comes first?" Aboriginal forestry looks to a strong and sustainable forest industry based on much more than logging, and the timing is ripe to develop this industry. In order to take full advantage of this opportunity, however, we need people with wellrounded skills, in both the traditional Aboriginal and modern forestry practices. The more trained people we have, the greater our involvement in the forestry industry - the greater our involvement in the industry, the more trained people we need. Hence the chicken and the egg.

A fifth barrier is financial resources. The federal government presently discharges its fiduciary responsibility over forests located on Indian reserve lands through forest management programs delivered by Forestry Canada through Forestry Resource Development Agreements (FRDA's). This programming is vastly inadequate and does not address Aboriginal values and the need for capacity building. Furthermore, the federal government announced it its budget of April 1993, that the FRDA's will not be renewed after the existing agreements expire. The federal responsibility for Indian lands however, continues to exist and could be more adequately fulfilled by providing Aboriginal communities with the financial resources necessary to manage our own forest lands.

I have just outlined some of the most obvious barriers to the enhancement of an Aboriginal Forestry, but these are by no means all of them. There are several avenues that can be followed to remove these barriers, such as community empowerment through the recognition of the inherent right to self-government, 
land claims settlement, and the implementation of a National Aboriginal Forest Strategy.

Many of the land claims agreements which are being negotiated across the country will or do incorporate aboriginal management or co-management of natural resources. As well, natural resource management would likely be a principle activity of any self-governing First Nation. Land claims settlements and self-government agreements, however take years to negotiate, and the need for Aboriginal control over our forest resources is an urgent one.

Recognizing the urgency of this need, the National Aboriginal Forestry Association (NAFA) was created by forestry-minded Aboriginal people in late 1989 to promote the interests and needs of Aboriginal communities in the forest sector. Our overall goal is to encourage and support increased Aboriginal involvement in forest management and related commercial opportunities. Our primary focus is building a policy framework for Aboriginal forest management that is consistent with the overall goals of self-determination and self-reliance as expressed by our national Aboriginal organizations.

NAFA's specific objectives are:

- To ensure that the damage to forest lands both on and off reserves is repaired to reverse the environmental degradation that has characterized much of reserve forest lands.

- To conduct high profile projects:

- to raise the Aboriginal conscience about the practice of forestry;

- to teach alternatives to the "conventional wisdom" in land use;

- to promote sustainable forest resource use; and

- to ensure that communities are made aware of ways and means to extract the highest value from their resources.

- To be an advocate seeking out opportunities to promote forestry amongst and on behalf of Aboriginal people with governments and industry.

As a first step towards enabling aboriginal communities to control and manage our natural resources, NAFA has been aggressively working at the national policy level. Since its creation, NAFA has worked on nurturing consensus among Aboriginal communities on an Aboriginal forest strategy; drafted a comprehensive legislative proposal with the Intertribal Forestry Association of British Columbia (IFABC); developed a code of practice to establish minimum guidelines for the practice of Aboriginal forestry; and participated in the drafting of a national sustainable forest strategy:

Canada's National Forest Strategy is a comprehensive and visionary approach to sustainable forest resource development in Canada. In Strategic Direction Seven of the Strategy, which focuses on Aboriginal Peoples, it recognizes to some extent the prerequisites for increased Aboriginal participation in the forest sector. It recognizes both the importance of the forest sector for Aboriginal communities and the responsibilities of governments to respect our Aboriginal and treaty rights. As well, it clearly identifies the need for improved access to resources. Strategic Direction Seven outlines four principles which called for:

- Forest,management practices that recognize the rights of Aboriginal people who rely on the forests for their livelihood and cultural identity.
- Increased access to resources for self-sufficiency through economic development.

- An integral role for Aboriginal communities in planning and management of forest resources within areas of traditional use.

- Cooperative resolution of land claims and Aboriginal selfgovernment for a stable environment for long-term sustainable forest management.

The Framework for Action outlined in Strategic Direction Seven contains six general elements including:

- Development of an Aboriginal forest strategy that respects the shared beliefs and aspirations of Aboriginal people and deals with regeneration of reserve lands, empowerment of communities to manage their forest resources and development of models for sustainable forest management.

- Respect for Aboriginal and treaty rights in development and application of government legislation and policies.

- Cooperation to encourage Aboriginal business development through improved access to capital, technology transfer and infrastructure support.

- Cooperation to complete strategic reviews of forest-based business opportunities for Aboriginal communities, consistent with traditional values and uses in the forst-based economy.

- Completion of a strategy to address training and employment needs of Aboriginal people.

- Broadening of programs by post-secondary and professional educational institutions to reflect the Aboriginal land ethic, as well as the constitutional status and positions of Aboriginal people.

As a signatory to the Canada Forest Accord, NAFA agrees that an Aboriginal Forest Strategy is needed urgently and has been working to identify what we believe the components of that strategy will need to be.

The first component of an Aboriginal Forest Strategy is the empowerment of Communities. NAFA has proposed the First Nations Forestry Resource Management (FNFRM) Act as optional legislation to replace the colonial approach of the Indian Act. The Department of Indian and Northern Affairs Canada (INAC) has the lead role in the promotion of this legislation. Issues such as the inherent right to self-government must be respected in any legislation which requires the wide support of First Nations.

The second component is an Indian Forest Lands Programme. This new comprehensive program which would be delivered by Aboriginal institutions is required to restore the productivity of Indian forest lands to levels to be expected of a good manager. The Indian Forest Lands Program initiative is particularly crucial now that the federal government has announced its intention to not renew Federal/Provincial Forest Resource Development Agreements.

The third component of an Aboriginal Forestry Strategy is training and education in forestry. Employment and Immigration Canada spends billions on labour force development. We are suggesting that the proportion now expended on forestry skill development become more focused on Aboriginal needs in the 
sector and that Aboriginal institutions take a lead role in linking that programming with the opportunities.

The fourth component is business development. NAFA is proposing an Aboriginal Forest Sector Business Development Strategy based on five main themes:

- A forest industry overview to identify prime sectors for Aboriginal participation;

- Analysis of barriers to entry faced by Aboriginal entrepreneurs;

- Development of models for successful Aboriginal participation;

- Development of information exchange mechanisms to increase Aboriginal awareness and to create awareness within the industry of products and services that Aboriginal enterprises can provide; and

- Business development support services with a market orientation which will strengthen Aboriginal business capabilites.
With a forest sector business development strategy and better access to resources, Aboriginal communities will be on their way to economic development and self-reliance.

Overall it is NAFA's view that now is the time to implement an Aboriginal Forestry Strategy. With the public's concern for environmental matters; governments concerned with how to respond to demands for sustainable use of natural resources; an industry looking for stable working relationships; it is opportune to include Aboriginal peoples in the restructuring process that is now ongoing.

As you have heard today, we have a clear idea of how we should be included in that restructuring process. We cannot, however, achieve such inclusion alone. We need the support of the forestry industry as a whole. As well, we need a firm commitment on the part of the federal government, a commitment that is acted upon and fulfilled. We hope that you as members of the forestry industry will stand with us in our efforts to gain that federal commitment.

\section{Frais d'adhésion 1994-1995}

\section{Membre actif}

Première et deuxième année suivant la graduation (graduation de 1993 et de 1992$) *(2.49$ \$ de T.P.S. inclus)

Nouveau membre pour une première année * $(2.49 \$$ de T.P.S. inclus)

Marié ou équivalent

Deuxième adhésion seulement * $(2.49 \$$ de T.P.S. inclus $)$

Tout autre membre actif * $(2.49 \$$ de T.P.S. inclus $)$

\section{Autres catégories de membres}

Membre à la retraite (afin d'obtenir le statut de membre à la retraite, ce dernier doit être membre de l'Institut depuis quinze ans)

$*(2.49 \$$ de T.P.S. inclus $)$

Membre étudiant * $(1.31 \$$ de T.P.S. inclus)

Membre de soutien (membre de l'IFC/CIF)

Membre corporatif $*(4.98 \$$ de T.P.S. inclus $)$

Suite à une demande écrite, le conjoint d'un membre actif peut obtenir une réduction de ses frais d'adhésion en fonction d'un mon tant déterminé annuellement. Les membres conjoints sont membres d'une même section, demeurent ensemble en tant que conjoints et utilisent la même adresse postale.

L'année budgétaire de l'Institut débute le 1er juillet pour se terminer le 30 juin. Les demandes d'adhésion effectuées après le 1er janvier 1995, seront facturées à la moitié des frais d'adhésion de l'Institut pour l'année en cours. Aucun frais d'adhésion ne sera facturé au membre soumettant une demande après le ler avril pour la durée de l'année en cours.

\section{Le frais de section s'additionnent à ce montant et varient de $5.00 \$$ à $30.00 \$$ pour l'année budgetaire de l'Institut.}

*N.B.: La portion des frais d'adhésion couvrant les frais du Forestry Chronicle est assujettie à la T.P.S. Pour les fins de la taxe, ce coût est calculé sur une base de 38.00 \$ et correspond à 2.49 \$ de T.P.S. (sauf pour le taux étudiant de 20.00 \$, soit 1.31 \$ de T.P.S.) 